\title{
ANALISIS PERAN ORANG TUA SEBAGAI PENGGANTI GURU SEKOLAH DI MASA PANDEMI COVID-19 SISWA SMP NEGERI 1 PANAI TENGAH KABUPATEN LABUHANBATU
}

\author{
Puji Rahayu ${ }^{1}$, Rohana $^{2}$, Eka Febriani ${ }^{3}$ \\ FKIP ULB, Indonesia \\ *Corresponding Author: hanasyarif85@gmail.com
}

\section{Article History}

Received : April 16 $6^{\text {th }}, 2021$

Revised : April 27 2021

Accepted : May $10^{\text {th }}, 2021$

Published : May $18^{\text {th }}, 2021$

\begin{abstract}
Abstrak: Indonesia di kabarkan dengan adanya kemunculan virus covid-19 yang merupakan penyakit menular. Sehingga berimbas pada pembatasan aktivitas salah satunya sekolah. Muncul kebijakan yang memaksa guru dan murid tetap bekerja dan belajar di dalam rumah. Kebijakan ini tentunya tidak hanya berdampak pada relasi guru dan murid selama belajar di rumah. Namun juga pentingnya optimalisasi peran orang tua dalam pelaksanaan belajar di rumah. Penelitian ini bertujuan untuk mendeskripsikan peran orang tua sebagai pengganti guru sekolah pada masa pandemi covid-19 siswa SMP Negeri 1 Panai Tengah Kabupaten Labuhanbatu. Metode penelitian menggunakan metode deskriptif kualitatif. Penelitian ini dilaksanakan pada bulan Desember - Januari 2020. Responden penelitian ini yaitu orang tua siswa SMP Negeri 1 Panai Tengah sebanyak 64 orang. Instrumen penelitian yaitu melalui penyebaran angket. Analisis data nya menggunakan reduksi data penyajian data dan kesimpulan. Pembelajaran di rumah sangat efektif untuk diterapkan namun bukan berarti pembelajaran di sekolah tidak efektif dibandingkan kegiatan pembelajaran di rumah. Guru memberikan tugas karena terbatasnya waktu belajar dan sulitnya berinteraksi selama pembelajaran dirumah, oleh karena itu banyak sebagian guru yang mengganti hal tersebut menjadi pemberian tugas untuk memantapkan kemampuan anak mengenai materi yang dipelajari. Maka, sebagai orang tua wajib memberikan motivasi kepada anaknya belajar di rumah, baik dalam keadaan orang tua bekerja maupun orang tua yang hanya menjadi ibu rumah tangga. Orang tua berperan untuk membimbing anaknya dalam belajar, tugas orang tua juga di harapkan sebagai pembimbing, pendidik, penjaga dan pengawas. Dan peran serta orang tua dalam melakukan pembelajaran dirumah sebagai pintu terdepan untuk meningkatkan hasil belajar dan prestasi anak.
\end{abstract}

Kata Kunci : Peran orang tua, Pengganti Guru Sekolah, Pandemi Covid-19, Siswa SMP

\section{PENDAHULUAN}

Belakangan ini seluruh dunia khusunya indonesia di gemparkan dengan adanya kemunculan virus covid-19. Coronavirus adalah virus yang termasuk RNA strain yang tunggal positif yang menginfeksikan saluran pada pernapasan, yaitu mempunyai tanda gejala berupa demam, batuk, dan sulit dalam sistem pernapasan. Sedangkan menurut (Adityo, 2020) menyatakan bahwa COVID-19 merupakan penyakit yang terbaru sehingga menjadi pandemi. Pada penyakit ini merupakan penyakit yang menular yang relatif sangat cepat sehingga memiliki mprtalitas yang tidak bisa diabaikan, sebelum terdapat definitif. Jadi berdasarkan penjelasan sebelmunya dapat disimpulkan bahwa
Coronavirus atau COVID-19 merupakan suatu penyakit yang berjenis virus corona kemudian virus ini termasuk RNA strain yang tunggal positif yang penularannya sangat cepat dan mempunyai gejala ketika sudah terkena virus corona atau COVID-19 antara lain batuk, demam, dan sulit pada saluran pernapasan. Menurut Euis Kurniati, dkk (2020) menyatakan segala upaya dilakukan pemerintah untuk pencegahan penyebaran virus ini, di antaranya adalah dengan mengeluarkan PP Nomor 21 tahun 2020 tentang Pembatasan Sosial Berskala Besar Dalam Rangka Percepatan Penanganan Covid-19 yang berimbas pada pembatasan berbagai aktivitas termasuk di antaranya sekolah. Kebijakan ini memaksa guru dan murid untuk tetap bekerja dan belajar dari rumah. Kebijakan 
ini tentunya tidak hanya berdampak pada relasi guru dan murid selama Belajar di rumah. Namun juga pentingnya optimalisasi peran orang tua dalam pelaksanaan belajar di rumah.

Menurut Haerudin (2020) Pandemi Covid19 ini telah mengganti pola pembelajaran yang semestinya tatap muka menjadi pembelajaran jarak jauh atau biasa disebut daring. Nyatanya Keterbatasan pengetahuan akan penggunaan teknologi menjadi salah satu kendala dalam sistem pembelajaran daring ini. Terutama orang tua pada situasi ini dituntut untuk membimbing anak - anaknya dalam pembelajaran berbasis internet, selain itu kendala yang saat ini muncul yaitu banyaknya keluhan para orang tua menengah ke bawah di sebabkan akan adanya pembelajaran daring ini yang memaksakan mereka harus lebih bekerja keras demi bisa memenuhi kebutuhan anaknya yang ingin belajar, salah satunya pendukung pembelajarn daring ini adalah gadget dan kuota internet. Bagi orang tua siswa yang terbiasa menggunakan teknologi dan mampu membeli dan memenuhi kebutuhan anaknya dalam belajar daring mungkin tidak menjadi masalah, tetapi bagi orang tua siswa yang awam akan penggunaan teknologi dan tidak mampu untuk membelinya menjadi tantangan tersendiri dalam membimbing anaknya kala situasi ini. Hal ini tentu bukan suatu hal yang mudah bagi semua kalangan Pendidikan terutama orang tua menghadapi transisi dalam sistem pembelajaran ini. Maka dari pada itu pemerintah hendaknya bijak dalam menerapkan kebijakan, artinya jika pemerintah mampu membuat peraturan belajar dari rumah, pemerintah harus mampu memfasilitasi berbagai kebutuhan anak sekolah yang hendak di gunakan dalam belajar. Peran serta orang tua siswa dalam sistem belajar dirumah ini tidak bisa dipungkiri. Jika Dokter sebagai pintu terdepan dalam menangani Covid19, maka Orang tua baik ibu maupun ayah sebagai garda terdepan untuk mengawal anak anaknya tetap belajar dirumah masing - masing. Harapan saya sebagai peneliti agar para orang tua juga harus mampu sebagai pembimbing, pendidik, penjaga, pengembang dan pengawas terhadap anak yang sedang belajar di rumah. Juga kepada pemerintah harapan saya agar lebih bijak dalam berbuat dan bertindak sebelum mengeluarkan kebijakan, karena para orang tualah yang menanggung segala keputusan pemerintah dengan adanya belajar dari rumah berbasis online.

Peran orang tua sangat dibutuhkan utuk memberikan pendidikan kepada anak - anaknya yang belum bisa memahami tentang pandemi yang sedang mewabah untuk tetap berdiam diri dirumah agar tidak terlular dan menularkan wabah pandemi ini. Peran orang tua dalam situasi pandemi Covid-19 ini memiliki kedudukan yang fundamental. Mengingat kembali pentingnya peranan orang tua dalam mendidik anak, beberapa penelitian sudah membuktikan bahwasanya orang tua memiliki andil yang sangat besar untuk kemampuan anak dalam lingkup Pendidikan. Salah satunya penelitian yang dilakukan (Haerudin et al., 2020) dimana penelitian ini menunjukkan peran orang tua dalam menentukan prestasi belajar siswa sangatlah besar. Orang tua yang tidak memperhatikan pendidikan anaknya dapat menyebabkan anak kurang atau bahkan tidak berhasil dalam belajarnya. Sebaliknya, orang tua yang selalu memberi perhatian pada anaknya, terutama perhatian pada kegiatan belajar mereka dirumah, akan membuat anak lebih giat dan lebih bersemangat dalam belajar karena ia tahu bahwa bukan dirinya sendiri saja yang berkeinginan untuk maju, akan tetapi orang tuanya juga memiliki keinginan yang sama. Sehingga hasil belajar atau prestasi belajar yang diraih oleh siswa menjadi lebih meningkat. Peran orang tua menjadi sangat penting ketika anak mulai bersekolah di rumah. Karena orang tua atau keluarga terdekat pada dasarnya adalah tempat pendidikan yang pertama bagi anak.

Orang tua mempunyai tugas membantu anak dalam mempersiapkan media yang akan digunakan anak dalam belajar, mendampingi proses belajarnya dan masih banyak lagi peran orang tua yang dapat memaksimalkan proses belajar mengajar di rumah melalui daring. Menurut (Umar, 2015)Orang tua berperan penting dalam menentukan keberhasilan pendidikan anak-anak mereka. Induk peran dan tanggung jawab antara lain dapat diwujudkan dengan membimbing kelangsungan anak belajar di rumah sesuai dengan program yang telah dipelajari oleh anak-anak di sekolah belajar. Membimbing anak-anak belajar di rumah dapat dilakukan dengan mengawasi dan membantu pengaturan tugas sekolah serta menyelesaikan instrumen dan infrastruktur anak belajar Pendidikan anak adalah tanggung jawab orantgua. Belajar disekolah tetap peran orang tua paling utama, sekarang ini banyak terlihat bahwa seolah-olah sekolah memegang peran utama dalam proses mendidik anak, sehingga lepas tanggung jawab. Dimasa pandemik ini, itu tidak akan dipakai lagi, pembelajaran dirumah dituntut 
orang tua mengembalikan fungsinya bahwa merekalah pendidik seumur hidup dan menjadikan sekolah menjadi mitra dalam perkembangan anak. Menurut Mastura, dkk (2020) Pandemi covid-19 mengharuskan peserta didik untuk belajar jarak jauh dan belajar dirumah dengan bimbingan dari orang tua. Karena pandemi ini, peserta didik kurang dalam mempersiapkan diri. Seperti motivasi peserta didik yang kurang dalam mengikuti pembelajaran daring. Menurut (Mastoah \& MS, 2020) Permasalahan yang dirasakan oleh semua rakyat Indonesia selama masa Covid yang mengharuskan untuk terus menerus berada di rumah saja, hal ini tentu akan menimbulkan rasa boring dan stress pada orang tua, terlebih anak. Oleh karena itu, orang tua harus mengerti bagaimana cara agar anak tidak bosan dan jenuh selama berada di rumah. Oleh karena itu, orang tua harus bisa menciptakan lingkungan yang aman, nyaman, harmonis dan kasih sayang dalam keluarga untuk mempererat emosional orang tua dengan anak, terlebih lagi selama masa pandemi yang mengharuskan anak dan orang tua harus terus menerus berada di rumah. Resiko dari penutupan elemen Pendidikan secara fisik dan mengubah dengan belajar dari rumah sebagaimana peraturan pemerintah adalah adanya perubahan sistem belajar mengajar, pengelola sekolah, siswa, orang tua, dan tentu saja guru harus bermigrasi ke sistem pembelajaran digital atau online, yang lebih dikenal dengan istilah elearning(Wahyono et al., 2020) atau dikenal dengan istilah pembelajaran dalam jaringan atau "pembelajaran daring" di Indonesia.

Sistem pembelajaran jarak jauh merupakan suatu alternatif pemerataan kesempatan dalam bidang pendidikan. Tujuan dari pembangunan sistem ini antara lain menerapkan aplikasiaplikasi pembelajaran jarak jauh berbasis web pada situs-situs pembelajaran jarak jauh yang di kembangkan, karena sistem ini terdiri dari kumpulan aplikasi-aplikasiyang dapat di gunakan sebagai alat bantu dalam kegiatan pembelajaran jarak jauh hingga penyampaian materi pembelajaran jarak jauh dapat dilakukan dengan baik. Berdasarkan hasil penelitian yang dilakukan oleh Munir (2012) Sarana menunjang dari pembelajaran jarak jauh ini adalah teknologi informasi dan komunikasi. Kemunculan teknologi informasi dan komunikasi pada pembelajaran jarak jauh ini sangan membantu sekali. Seperti dapat di lihat dengan munculnya pembelajaran secara online, baik pendidikan formal atau non formal dengan menggunakan fasilitas internat. Menurut (Anugrahana, 2020) media pembejaran online atau sering disebut dengan e-learning merupakan media penunjang pendidikan dan bukan sebagai media pengganti pendidikan. Prosesnya e-learning sebagai media distance learning menciptakan paradigma baru, yakni peran guru yang lebih bersifat "fasilitator" dan siswa sebagai "peserta aktif" dalam proses belajar-mengajar. Karena itu, guru dituntut untuk menciptakan teknik mengajar yang baik, menyajikan bahan ajar yang menarik, sementara siswa dituntut untuk aktif berpartisipasi dalam proses belajar. Pembejaran online juga sering disebut dengan pembelajaran daring atau "dalam jaringan (online)". Pemanfaatan sistem pembelajaran daring merupakan salah satu upaya yang bisa dilakukan untuk mengatasi permasalahan dan memudahkan siswa mengakses materi pembelajaran. Meskipun menyadari bahwa ada disparitas terhadap akses teknologi pembelajaran dan beragamnya latar belakang orang tua, Kementerian Pendidikan dan Kebudayaan Republik Indonesia dengan tegas memberlakukan kebijakan pembelajaran daring (Wahyono et al., 2020). Tugas orangtua terutama ibu, pada saat ini menjadi bertambah berat setelah pemerintah memutuskan penerapan kebijakan proses belajar mengajar yang diubah menjadi online artinya belajar dari rumah menggunakan media belajar yang sudah di tetapkan sekolah selama pandemic Covid-19. Pendampingan orang tua dalam pembelajaran dari rumah selain membantu anak dalam momen belajar juga akan membangun komunikasi yang baik dengan anak. Komunikasi yang baik ini akan membangun kreativitas anak lewat berbagai aktivitas bersama yang bermanfaat (Iftitah \& Anawaty, 2020). Sebenarnya dari berbagai Dinas Pendidikan dan Kebudayaan Jakarta, terdapat panduan aturan seperti dalam akun Instagram tentang tugas untuk kepala sekolah, guru, orang dan siswa. Misalnya tugas Kepala Sekolah adalah memberikan surat tugas kepada guru serta surat edaran kepada orangtua untuk melakukan kegiatan pembelajaran di rumah, dalam rangka meningkatkan kewaspadaan dan pencegahan penularan virus corona di sekolah. Kepada para guru juga ada tugas, misalnya menyiapkan bahan ajar yang akan diunggah kepada siswa, menentukan media belajar seperti grup Google Clasroom, Whatsapp, Email, atau aplikasi media belajar lain sesuai rekomendasi Kemendikbud. Kepada para orang tua juga diminta untuk memastikan siswa melaksanakan kegiatan belajar di rumah masing-masing, membatasi izin 
kegiatan di luar rumah, berkoordinasi dengan wali kelas, guru atau sekolah, membantu siswa menerapkan pola hidup bersih sehat (PHBS) di rumah dan sebagainya. Kepada para siswa diminta mempelajari bahan atau materi mata pelajaran yang diunggah guru melalui media yang telah disepakati. Kemudian melakukan diskusi dengan guru melalui media online jika masih ada hal yang kurang jelas dari materi yang diberikan. Bagi orangtua dengan latar belakang pendidikan yang memadai serta didukung dengan fasilitas atau sarana yang lengkap, mendampingi anak untuk belajar di rumah mungkin tidak akan terlalu berat. Yang diperlukan adalah kesediaan dan kesabaran untuk tetap berada di samping anak-anaknya. Lain haln ya dengan orangtua yang tingkat pendidikannya kurang memadai, menjadi guru bagi anak-anak mereka bukanlah perkara mudah. Selain itu keterbatasan akses informasi juga menjadi kendala tersendiri bagi sebagian orangtua dalam membimbing anakanaknya. Beratnya tantangan dalam mendidik anak sendiri di rumah pada akhirnya membuat sebagian orangtua bereaksi terhadap kebijakan sekolah yang memberikan tugas terlalu banyak kepada anak-anak mereka. Sebagian bahkan melapor kepada pihak Komisi Perlindungan Anak Indonesia (KPAI) karena anak serta orangtua mengalami stress dengan banyaknya tugas yang harus diselesaikan.

Peran orang tua dalam mendampingi kesuksesan anak selama belajar di rumah menjadi sangat sentral, sekaitan dengan hal tersebut (Kurniati et al., 2020) merilis berbagai panduan bagi orang tua dalam mendampingi putra-putri selama pandemi ini berlangsung yang meliputi tips pengasuhan agar lebih positif dan konstuktif dalam mendampingi anak selama beraktivitas di rumah. Orang tua pada awalnya berperan dalam membimbing sikap serta keterampilan yang mendasar, seperti pendidikan agama untuk patuh terhadap aturan, dan untuk pembiasaan yang baik (Kurniati et al., 2020) namun perannya menjadi meluas yaitu sebagai pendamping pendidikan akademik. Mendampingi anak ketika belajar adalah sesuatu yang sangat penting bagi anak yaitu dapat membangun kedekatan antara orang tua dengan anak, belajar mengajaknya berdiskusi agar mengetahui bagaimana pola berpikir anak. Adapun Peran penting orang tua dalam mendampingi anak yaitu (Iftitah \& Anawaty, 2020)

a. Anak merasa tidak sendiri

Orang tua mendampingi anak agar anak merasa tidak sendiri. Pendampingan yang dilakukan oleh orang tua membuat anak akan merasa nyaman akan membangkitkan rasa percaya diri anak. Di saat menghadapi permasalahan, ada orang tua yang akan melindunginya (Sundari \& Yoridho, 2018). Dengan begitu, Anak merasa orang tua memperhatikan, melindungi dan memberikan kasih sayang. Hal tersebut dapat meningkatkan kedekatan orang tua dan anak, akan membangkitkan rasa percaya diri anak

b. Tempat berdiskusi dan bertanya

Orang tua adalah tempat sosial pertama bagi anak. Peran orang tua di rumah juga dapat dijadikan teman diskusi. Anak akan lebih terbuka jika orang tuanya juga terbuka dan memberi waktu luang untuk berdiskusi

c. Membantu mengenali diri sendiri

Mengenali diri sendiri sebagai sarana memudahkan kita untuk memahami orang lain. Mengenal diri sendiri bisa menjadi titik awal untuk menuju kebahagiaan dan kedamaian hidup. Kebahagiaan setiap orang pun berbedabeda, seperti jabatan tinggi, kekayaan, keluarga yang sempurna, dan sebagainya. Anak membangun jati dirinya bersama orang terdekat. Disinilah peran orang tua untuk membentuk karakter dan sikap anak agar terbentuk pribadi yang baik.

d. Melihat dan mengembangkan bakat anak

Orang tua harus dan mampu bertanggung jawab untuk menemukan bakat dan minat anak, sehingga anak diasuh dan dididik, baik langsung oleh orangtua atau melalui bantuan orang lain, seperti guru, sesuai dengan bakat dan minat anak sendiri, sehingga anak dapat memperoleh prestasi belajar secara lebih optimal(Umar, 2015).

e. Menciptakan lingkungan yang kondusif untuk belajar

Orang tua harus dapat menciptakan lingkungan dan suasana belajar yang aman dan nyaman sehingga anak dapat belajar dengan baik, suasana belajar dibuat secara natural (alami).

Dalam pelaksanaan belajar jarak jauh guru dan Orang tua akan lebih aktif bekerja sama ketika mendampingi anak di rumah. Dapat dikatakan pula bahwa situasi pandemi covid-19 ini mengembalikan hakikat pendidikan anak dalam keluarga, mencoba untuk memanfaatkan ilmu teknologi untuk menyikapi masalah pembelajaran jarak jauh dengan cara memberikan materi serta tugas pelajaran melalui online. Namun hal ini tidaklah selalu berjalan dengan mulus, terdapat banyak rintangan dalam pelaksanaannya yang kemudian timbul akibat 
pelaksanaan kegiatan belajar mengajar secara daring. Misalnya pengaturan waktu belajar dan bermain anak-anak yang cenderung lebih banyak bermainnya daripada belajarnya ketika ada di rumah. Hal tersebut bisa terjadi karena anak akan merasa nyaman berada di rumah dan menganggap bahwa rumah adalah daerah kekuasaannya. Oleh karena itu, perlu aturan belajar yang jelas dan disepakati bersama antara orang tua dan anak tanpa harus ada hukuman atau menekan anak. seperti paket data internet dan sinyal yang kurang memadai, bahkan ada beberapa pelajar tidak mempunyai penunjang Handphone yang baik, dan hal ini mengakibatkan materi pembelajaran tidak tersampaikan dengan baik dan merata, sehingga banyak pelajar yang kurang paham dan merasa tidak terbimbing dengan baik dalam memahami pelajaran di sekolah. Oleh sebab itu, dibutuhkan peran orang tua sebagai pengganti guru sekolah di rumah dalam membimbing anaknya selama proses pembelajaran jarak jauh. Menurut Winingsih (2020) terdapat empat peran orang tua selama Pembelajaran Jarak Jauh (PJJ) yaitu:

1. Orang tua memiliki peran sebagai guru di rumah, yang di mana orang tua dapat membimbing anaknya dalam belajar secara jarak jauh dari rumah.

2. Orang tua sebagai fasilitator, yaitu orang tua sebagai sarana dan pra-sarana bagi anaknya dalam melaksanakan pembelajaran jarak jauh.

3. Orang tua sebagai motivator, yaitu orang tua dapat memberikan semangat serta dukungan kepada anaknya dalam melaksanakan pembelajaran, sehingga anak memiliki semangat untuk belajar, serta memperoleh prestasi yang baik.

4. Orang tua sebagai pengaruh atau director.

Orang tua mempunyai peran untuk selalu membimbing anaknya agar dapat mencapai keberhasilan di masa yang akan datang. Orang tua juga berperan untuk mengarahkan anak sesuai dengan bakat dan minat yang dimiliki oleh masing-masing anak. Hal ini dikarenakan anak mempunyai bakat yang berbeda-beda. Anak memiliki hak untuk mewujudkan cita-citanya. Anak harus selalu dingatkan agar tidak larut dalam situasi libur sekolah yang tidak menentu seperti

saat ini.

\section{METODE}

Penelitian ini menggunakan deskriptif kualitatif. Tempat penelitian yang di teliti adalah SMP Negeri 1 Panai Tengah, Kelurahan Labuhanbilik, Kecamatan Panai Tengah, Kabupaten Labuhanbatu, Provinsi Sumatera Utara. Penelitian ini di laksanakan pada bulan Desember - Januari 2020. Responden yang di gunakan yaitu orang tua siswa untuk mendapatkan data-data kemudian menjabarkan hasil penelitian sebagai tanda tercapainya tujuan penelitian. Orang tua siswa sebanyak 64 orang kelas VIII-1 dan VIII-2 SMP Negeri 1 Panai Tengah. Data dikumpulkan melalui angket. Angket adalah pengumpulan data yang berupa pernyataan yang tertulis untuk responden. Analisis datanya menggunakan Reduksi data merupakan proses pengumpulan data penelitian, seorang peneliti dapat menemukan kapan saja waktu untuk mendapatkan data yang banyak, apabila peneliti mampu menerapkan metode observasi, wawancara atau dari berbagai dokumen yang berhubungan dengan subjek yang di teliti. Makanya pada tahap ini, si peneliti harus mampu merekam data lapangan dalam bentuk catatan-catatan lapangan (field note), harus di tafsirkan, atau di seleksi masing-masing data yang relevan dengan fokus masalah yang di teliti. Penyajian data yang telah di peroleh ke dalam sejumlah matriks atau daftar kategori setiap data yang di dapat, penyajian data biasanya di gunakan berbentuk teks naratif. Biasanya dalam penelitian, kita mendapat data yang banyak. Data yang kita dapat tidak mungkin kita paparkan secara keseluruhan. Untuk itu, dalam penyajian data penelitian dapat di analisis oleh peneliti untuk di susun secara sistematis, atau simultan sehingga data yang di peroleh dapat menjelaskan atau menjawab masalah yang di teliti. Maka dalam penyajian data, peneliti di sarankan untuk tidak gegabah mengambil kesimpulan.

Kesimpulan, merupakan analisis lanjutan dari reduksi data, dan penyajian data sehingga data dapat di simpulkan sementara, masih dapat diuji kembali dengan data di lapangan, dengan cara merefleksi kembali, peneliti dapat bertukar pikiran dengan teman sejawat, triangulasi, sehingga kebenaran ilmiah dapat tercapai. Bila proses siklus interaktif ini berjalan dengan kontinu dan baik, maka keilmiahannya hasil penelitian dapat di terima. Setelah hasil penelitian telah di uji kebenarannya, maka peneliti dapat menarik kesimpulan dalam bentuk deskriptif sebagai laporan penelitian. 


\section{HASIL DAN PEMBAHASAN}

\section{Hasil Angket}

Berdasarkan data yang telah di muat dapat di ketahui bahwa 87,5 \% banyak orang tua menilai bahwa melalui pembelajaran di rumah dapat mempererat hubungannya dengan anaknya, begitupun anaknya dinilai dapat melakukan pembelajaran di rumah dengan sangat baik. Hal ini sesuai dengan hasil penelitian (Sun'iyah, 2020) peristiwa pandemi memberikan hikmah yang berarti dimana mampu mempererat hubungan orang tua dan anak. Ketika di waktu normal orang tua disibukkan dengan pekerjaan, maka di kejadian luar biasa ini orang tua mempunyai banyak waktu luang untuk dapat mengamati perkembangan anak dan dapat mendengarkan keluh-kesah anak untuk dapat dicarikan solusinya. $87,8 \%$ orang tua menyatakan setuju semenjak pembelajaran dirumah melalui daring, anak lebih sering menggunakan hp sehingga lupa akan berkomunikasi bersama orang tua dan saudara. Hal ini tidak sejalan dengan pada masa pembelajaran aktif di sekolah sebelum masa pandemi covid-19, baik itu pembelajaran di rumah maupun di sekolah tidak ada pengaruh untuk merenggangkangkan hubungan orang tua dan anak, bagaimana pun sehabis pulang sekolah anak akan kembali bersama orang tua. Orang tua juga merasa melalui pembelajaran di rumah, orang tua dapat melihat perkembangan baik segi kognitif maupun sikap anaknya dalam belajar. Berdasarkan hasil penelitian (Iftitah \& Anawaty, 2020) mendampingi anak ketika belajar adalah sesuatu yang sangat penting bagi anak yaitu dapat membangun kedekatan antara orang tua dengan anak. adapun peran penting orang tua dalam mendampingi anak yaitu Anak merasa tidak sendiri, orang tua sebagai pemberi semangat, memfasilitasi kebutuhan anak, tempat berdiskusi dan bertanya, membantu mengenali diri sendiri, melihat dan mengembangkan bakat anak dan menciptakan lingkungan yang kondusif untuk belajar.

Berdasarkan hasil analisis data 59,3\% menyatakan pembelajaran di rumah juga dinilai memiliki lebih banyak pengeluaran untuk pulsa maupun kuota internet demi mendukung proses pembelajaran, namun banyak dari orang tua merasa pembelajaran di sekolah maupun di rumah sama-sama memiliki pengeluaran yang banyak jika dilihat dari uang jajan yang keluar maupun faktor lainnya. Hal ini sesuai dengan hasil penelitian(Haerudin et al., 2020) bahwa kendala yang dihadapi para orang tua adalah adanya penambahan biaya pembelian kuota internet bertambah, teknologi online memerlukan koneksi jaringan ke internet dan kuota oleh karena itu tingkat penggunaaan kuota internet akan bertambah dan akan menambah beban pengeluaran orang tua, untuk melakukan permbelajaran online selama beberapa bulan tentunya akan diperlukan kuota yang lebih banyak lagi dan secara otomatis akan meningkatkan biaya pembelian kuota internet. $54,6 \%$ orang tua menyatakan dalam pemberian tugas guru sudah tau sejauh mana siswa memahami materi yang disampaikan, maka dari pada itu guru memberikan tugas tidak melampaui batas kemampuan siswanya. Hal ini sesuai dengan penelitian Puspitasari (2020) bahwa dengan menggunakan sistem pembelajaran secara daring ini, terkadang muncul berbagai masalah yang dihadapi oleh siswa dan guru, seperti materi pelajaran yang belum selesai disampaikan oleh guru kemudian guru mengganti dengan tugas lainnya, hal tersebut menjadi keluhan bagi siswa karena tugas yang diberikan oleh guru lebih banyak. Hal ini di dukung juga dengan penelitian sebelumnya yang menyatakan bahwa selama pembelajaran dirumah atau daring, banyak orangtua yang kurang dalam memahami materi yang diberikan oleh pihak sekolah atau guru, orangtua menganggap tugas yang diberikan terlihat sulit sehingga mereka sulit untuk menyampaikan kepada anak(HANDAYANI, 2020). 81,2\% pembelajaran di rumah lebih efektif untuk di lakukan bukan berarti pembelajaran di sekolah tidak lebih efektif dibandingkan dengan kegiatan pembelajaran di rumah. Hal ini dikarenakan pembelajaran di rumah lebih cenderung kepada banyaknya pemberian tugas yang dapat dibantu dibimbing pengerjaannya oleh orang tua di rumah, Pembelajaran di sekolah pada dasarnya akan menguntungkan siswa maupun orang tua, karena di sekolah guru dapat mengajarkan siswa dengan baik dan dapat meningkatkan kualitas pembelajaran anak. Hal ini berkaitan dengan penelitian (Haerudin et al., 2020) banyak dari orang tua yang setuju jika selama pembelajaran di rumah, orang tua lah yang juga ikut membantu mengerjakan tugas yang diberikan oleh guru, walaupun tidak sedikit juga yang merasa hal ini menjadi tambahan aktivitas orang tua selain mengerjakan pekerjaan rumah tangga.

Melalui pembelajaran di sekolah anak lebih banyak menghabiskan waktunya untuk belajar, sehingga jika pulang ke rumah anak tidak 
begitu sering membuka buku untu belajar. Namun orang tua mengatakan sedangkan belajar di sekolah saja malas, apalagi belajar di rumah yang hanya menggunakan handphone dan bantuan saya. Pembelajaran di rumah membantu anak dalam belajar, juga membantu meminimalisir terjangkitnya virus. Pembelajaran dirumah merupkan suatu hal positif dimana orang tua juga bisa membantu dan memperhatikan anak dalam mengerjakan tugas, hal ini serupa dengan penelitian (Yulianingsih et al., 2020) yang mendasari pentingnya keterlibatan orangtua dalam pendidikan adalah dapat mengkomunikasikan dengan baik kepada orang tua tentang kegiatan yang dilakukan oleh anak. Selain itu juga berkontribusi terhadap pencapaian tugas perkembangan anak, baik dalam aspek kognitif maupun aspek perkembangan lainnya. Adanya kegiatan pembelajaran di rumah memiliki manfaat bagi siswa maupun orangtuanya, sedikit banyak nya orang tua maupun siswa sadar akan pentingnya mengetahui teknologi dan mengaplikasikannya secara positif. orang tua menyatakan mendampingi anak belajar dari rumah, sambil orangtua mengerjakan pekerjaan yang harus diselesaikan atau pekerjaan sampingan di luar dari rumah memang menjadi tantangan tersendiri, maka di sisi lain jika anak belajar di sekolah seperti biasa akan lebih memudahkahkan orang tua untuk melakukan pekerjaan rumah dengan leluasa. Karena orang tua melakukan pekerjaan rutinitas sehari-hari, seperti mencuci baju dan memasak itu di lakukan di pagi hari, selain itu orang tua juga mempunyai pekerjaan sampingan seperti menderes kebun karet menyebabkan orang tua tidak memiliki cukup waktu utuk mengajarkan anak dalam belajar daringnya. Hal ini berkaitan dengan pendapat (Indahningrum, 2020) Beberapa orang tua tidak dapat menjalankan perannya dengan maksimal karena harus bekerja, namun juga terdapat orang tua yang sibuk bekerja tetapi bisa berperan dengan baik dalam kegiatan belajar anaknya.

Di samping itu bagi sebagian orang tua yang memang memiliki pendidikan tinggi tidak menjadi masalah dalam membantu anak mengerjakan tugas, lain halnya dengan orang tua yang memiliki pendidikan rendah. Menurut (Nofianti, 2020) hal ini sejalan dengan hasil peneliti seorang ahli psikologi anak bahwa orang tua dengan tingkat pendidikan tinggi lebih memperhatikan tumbuh kembang anaknya sesuai dengan kebutuhanya dan secara langsung akan memberikan perhatian ekstra, namun jika tingkat pendidikan orang tua yang rendah, akan berdampak pada kurangnya pengetahuan orangtua bagaimana seharunya perlakuan mereka sebagai orang tua mengenai peran pola asuh kepada anak sendiri sesuai dengan tahapan tumbuh kembangnya (umur anak), kebutuhanya dan kemandirianya. Tetapi, Sebagai orang tua sudah wajib memberikan motivasi kepada anaknya dalam belajar di rumah, baik dalam keadaan apapun agar dalam belajar dan mengerjakan tugas anak merasa bahwa orang tua lah salah satu yang memberikan dukungan dan rasa peduli terhadapnya, Karena motivasi adalah suatu penguatan atau dorongan yang bisa membuat anak giat dalam belajar. Peran penting orang tua selama proses pembelajaran dari rumah adalah menjaga motivasi anak, memfasilitasi anak belajar, menumbuhkan kreativitas anak, mengawasi anak, dan mengevaluasi hasil belajar Karena orang tua berperan untuk membimbing anaknya dalam belajar, tugas orang tua juga di harapkan sebagai pembimbing, pendidik, penjaga dan pengawas.Tugas dinilai mampu membantu siswa untuk mengerti materi lebih banyak karena latihan soal berupa tugas yang diberikan. Anak lebih senang belajar di sekolah karena langsung berinteraksi langsung dengan guru maupun teman karena pembelajaran dirumah dianggap hanya untuk bermain-main saja karena mereka rasa rumah adalah ruang lingkupnya yang bisa sesuka hati saja.

\section{KESIMPULAN}

Pembelajaran di rumah sangat efektif untuk diterapkan namun bukan berarti pembelajaran di sekolah tidak lebih efektif dibandingkan dengan kegiatan pembelajaran di rumah. Guru memberikan tugas karena terbatasnya waktu belajar dan sulitnya berinteraksi selama pembelajaran dirumah, oleh karena itu banyak dari sebagian guru yang mengganti hal tersebut menjadi pemberian tugas untuk memantapkan kemampuan anak mengenai materi yang dipelajari. Orang tua menyatakan Pembelajaran di sekolah pada dasarnya akan menguntungkan siswa maupun orang tua, karena di sekolah guru dapat mengajarkan siswa dengan baik dan dapat meningkatkan kualitas pembelajaran anak. Bagi sebagian orang tua yang memang memiliki pendidikan tinggi tidak menjadi masalah dalam membantu anak mengerjakan tugas, lain halnya dengan orang tua yang memiliki pendidikan rendah. Sebagai orang tua sudah wajib memberikan motivasi kepada 
anaknya dalam belajar di rumah, baik dalam keadaan orang tua bekerja (wanita karir) maupun orang tua yang hanya menjadi ibu rumahtangga. Sebagai orang tua, merasa pembelajaran di rumah memiliki banyak pengeluaran. Agar dalam belajar dan mengerjakan tugas anak merasa bahwa orang tua menjadi salah satu yang memberikan dukungan dan rasa peduli terhadap anak. Orang tua berperan untuk membimbing anaknya dalam belajar, tugas orang tua juga di harapkan sebagai pembimbing, pendidik, penjaga dan pengawas, namun menjadi tambahan aktivitas orang tua selain mengerjakan pekerjaan rumah tangga.

\section{UCAPAN TERIMA KASIH}

Terima kasih saya ucapkan kepada seluruh civitas akademik SMP Negeri 1 Panai tengah yang sudah menerima saya melakukan penelitian tentang Peran Orang Tua sebagai pengganti guru sekolah di Masa Pandemi Covid19. Dan terimakasih juga saya ucapkan kepada seluruh orang tua yang telah membantu saya dalam menyelesaikan angket penelitian sebagai bahan untuk Artikel Ilmiah.

\section{REFERENSI}

Adityo, d. (2020). Peran Orang Tua Dalam Membimbing Anak Selama Pembrlajaran dirumah Sebagai Upaya Memutus Covid19.

Anugrahana, A. (2020). Hambatan, Solusi dan Harapan: Pembelajaran Daring Selama Masa Pandemi Covid-19 Oleh Guru Sekolah Dasar. Scholaria: Jurnal Pendidikan Dan Kebudayaan, 10(3), 282289.

Haerudin, Cahyani, A., Sitihanifah, N., Setiani, R. N., Nurhayati, S., Oktaviani, V., \& Sitorus, Y. I. (2020). Pembelajaran Di Rumah Sebagai Upaya Memutus Covid19. Pembelajaran Di Rumah Sebagai Upaya Memutus Covid-19, May, 1-12.

HANDAYANI, T. (2020). Peran Orang Tua Dalam Membimbing Anak Pada Pembelajaran Daring Di Desa Ngrapah Kecamatan Banyubiru Tahun Pelajaran 2019/2020. Skripsi, Fakultas Tarbiyah Dan Ilmu Keguruan Program Studi
Pendidikan Guru Madrasah Ibtidaiyah. Institut Agama Islam Negeri Salatiga.

Iftitah, S. L., \& Anawaty, M. F. (2020). Peran Orang Tua Dalam Mendampingi Anak Di Rumah Selama Pandemi Covid-19. JCE (Journal of Childhood Education), 4(2), 71. https://doi.org/10.30736/jce.v4i2.256

ISP, S. M. (2020). Peran Orang Tua Sebagai Guru Di Rumah Pada Pembelajaran Daring Di Sd Negeri Kebonromo 3 Sragen Selama Pandemi Covid-19 .

Kurniati, E., Nur Alfaeni, D. K., \& Andriani, F. (2020). Analisis Peran Orang Tua dalam Mendampingi Anak di Masa Pandemi Covid-19. Jurnal Obsesi: Jurnal Pendidikan Anak Usia Dini, 5(1), 241. https://doi.org/10.31004/obsesi.v5i1.541

Mastoah, I., \& MS, Z. (2020). Kendala Orang Tua Dalam Mendampingi Anak Belajar Pada Masa Covid 19 Di Kota Serang. AsSibyan: Jurnal Pendidikan Anak Usia Dini, 5(2), 121-128. http://jurnal.uinbanten.ac.id/index.php/ass ibyan/article/view/3663

Mastura, R. S. (2020). Dampak Pandemi Covid19 Terhadap Proses Pengajaran Bagi Guru dan Siswa. Jurnal Studi Guru dan Pembelajaran .

Munir, D. (2012). Pembelajaran Jarak Jauh Berbasis Teknologi Informasi dan Komunikasi. Bandung: Alfabeta.

Nika Cahyati1, R. K. (2020). Peran Orang Tua Dalam Menerapkan Pembelajaran Di Rumah Saat Pandemi Covid 19 . Jurnal Golden Age, Universitas Hamzanwadi .

Nofianti, R. (2020). Daring Anak Usia Dini Di Msa Pandemic Covid 19 Di Tk Islam Ibnu Qoyyim. 13(2), 19-30.

Rahmi, M. (2020). Penguatan Peran Keluarga Dalam Mendampingi Anak Belajar Di Masa Pandemi Covid-19 . Jurnal Ilmiah Pendidikan Islam .

Resti Mia Wijayanti, P. Y. (2020). Perspektif dan Peran Orangtua dalam Program PJJ Masa Pandemi Covid-19 di PAUD . Jurnal Pendidikan Anak Usia Dini . 
Sun'iyah, S. L. (2020). Sinergi Peran Guru Dan Orang Tua Dalam Mewujudkan Keberhasilan Pembelajaran Pai Tingkat Pendidikan Dasar Di Era Pandemi Covid19. DAR EL-ILMI: Jurnal Studi Keagamaan, Pendidikan Dan Humaniora, 7(2), 1-16.

Tsaniya Zahra Yuthika Wardhani, H. K. (2020). Optimalisasi Peran Pengawasan Orang Tua Dalam Pelaksanaan Sekolah Online Di Masa Pandemi Covid-19 . Prosiding Penelitian \& Pengabdian Kepada Masyarakat .

Umar, M. (2015). Peranan Orang Tua Dalam Peningkatan Prestasi Belajar Anak. JURNAL EDUKASI: Jurnal Bimbingan Konseling, $\quad 1(1), \quad 20$. https://doi.org/10.22373/je.v1i1.315

Wahyono, P., Husamah, H., \& Budi, A. S. (2020). Guru profesional di masa pandemi
COVID-19: Review implementasi, tantangan, dan solusi pembelajaran daring. In Jurnal Pendidikan Profesi Guru (Vol. 1 , Issue http://ejournal.umm.ac.id/index.php/jppg/ article/view/12462

Yulianingsih, W., Suhanadji, S., Nugroho, R., \& Mustakim, M. (2020). Keterlibatan Orangtua dalam Pendampingan Belajar Anak selama Masa Pandemi Covid-19. Jurnal Obsesi : Jurnal Pendidikan Anak Usia Dini, 5(2), 1138-1150. https://doi.org/10.31004/obsesi.v5i2.740 